\title{
Prehypertension and hypertension among young Indonesian adults at a primary health care in a rural area
}

\author{
Felix F. Widjaja, Lucyana A. Santoso, Nadya R.V. Barus, Giovano A. Pradana, Citra Estetika
}

Faculty of Medicine, Universitas Indonesia, Jakarta, Indonesia

\begin{abstract}
Abstrak
Latar belakang: Prehipertensi dan hipertensi berhubungan dengan berbagai komplikasi pada hampir seluruh organ, tetapi sering diabaikan oleh dewasa muda di daerah pedesaan. Penelitian ini bertujuan untuk mengetahui prevalensi prehipertensi dan hipertensi pada dewasa muda di pelayanan kesehatan dasar di daerah pedesaan Cicurug, Kabupaten Sukabumi, Jawa Barat.

Metode: Studi potong lintang ini dilakukan di Pusat Kesehatan Masyarakat (Puskesmas) Cicurug, Kabupaten Sukabumi, Jawa Barat. Subjek penelitian adalah pasien balai pengobatan yang diambil secara konsekutif pada hari Senen sampai Sabtu pada bulan September 2012, berusia antara 18-25 tahun, tidak hamil atau dalam kondisi syok. Subjek diwawancara (usia, jenis kelamin, aktivitas fisik, waktu duduk, perilaku merokok, minum alkohol, dan riwayat keluarga) dan diperiksa oleh tenaga kesehatan (berat, tinggi, indeks massa tubuh [IMT], tekanan darah sistolik dan diastolik).

Hasil: Dari 111 dewasa muda, 34,2\% memiliki prehipertensi dan 17,1\% memiliki hipertensi. Jika dibandingkan menurut jenis kelamin, wanita lebih banyak mengalami prehipertensi, tetapi hipertensi lebih banyak terjadi pada pria. Riwayat keluarga dari ibu dan bapak tidak berhubungan baik dengan prehipertensi maupun hipertensi jika dibandingkan dengan normotensi. Aktivitas total tidak terlihat berhubungan dengan prehipertensi $(O R=2,6 ; p=0,052)$, dan juga hipertensi $(O R=1,758 ; p=0,498)$. IMT berhubungan dengan hipertensi $(O R=3,354 ; p=0,041)$, tetapi tidak berhubungan dengan prehipertensi $(O R=2,343 ; p=0,099)$.

Kesimpulan: Prevalensi prehipertensi dan hipertensi cukup tinggi pada dewasa muda di pelayanan kesehatan dasar di daerah pedesaan. Intervensi untuk mencegah penyakit yang lebih lanjut perlu dilakukan sejak dini dengan modifikasi gaya hidup karena tekanan darah berhubungan dengan faktor risiko yang dapat diubah, seperti IMT dan aktivitas total. (Med J Indones. 2013;22:39-45)
\end{abstract}

\begin{abstract}
Background: Prehypertension and hypertension were related with many complications of nearly every organ, but often neglected by young adults in rural area. This research was done to observe the prevalence of prehypertension and hypertension among young adult in a primary health care of rural area at Cicurug, Sukabumi District, West Java.

Methods: This cross-sectional study was done in Cicurug Public Health Center, Sukabumi District, West Java. The subjects were consecutively recruited from the outpatient clinic on Monday until Saturday in September 2012,18-25 years old, not pregnant nor having shock. They were interviewed about their age, gender, physical activity, sitting hours, smoking habit, alcohol consumption, and family history and examined by trained health professionals (weight, height, body mass index [BMI], systolic and diastolic blood pressure).

Results: From 111 young adults, $34.2 \%$ had prehypertension and 17.1\% had hypertension. Within sex groups, the prevalence of prehypertension was higher in females, whereas hypertension was occurred more in males. Neither of family history from mother nor father were associated with prehypertension and hypertension compared with normotension. Total activity was not associated with prehypertension $(\mathrm{OR}=2.6 ; \mathrm{p}=0.052)$ and hypertension $(\mathrm{OR}=1.758 ; \mathrm{p}=0.498)$. BMI was associated with hypertension $(\mathrm{OR}=3.354 ; \mathrm{p}=0.041)$ and not associated with prehypertension $(\mathrm{OR}=2.343 ; \mathrm{p}=0.099)$.

Conclusion: Prevalence of prehypertension and hypertension were relatively high among young adult in primary health care of rural area. Intervention to prevent further complications needs to be done early with lifestyle modification because blood pressure is associated with modifiable risk factors, such as BMI and total activity. (Med J Indones. 2013;22:39-45)
\end{abstract}

Keywords: Hypertension, prehypertension, rural area, young adult

According to the seventh report of the Joint National Committee on prevention, detection, evaluation, and treatment of high blood pressure (JNC-7), prehypertension is not a disease entity, rather it is a reminder to intervene the patients' lifestyle immediately in order to prevent its progression to hypertension. ${ }^{1}$ People with prehypertension have a three fold risk of developing hypertension compared with normotensive people. It is associated mostly with high body mass index (overweight and obesity), higher age ( $>45$ years old), and smoking. ${ }^{2}$
Prehypertension and hypertension are related to major morbidity, but often neglected by young adults in rural area. The burden of complications of hypertension has been well established in every organ. Meanwhile, prehypertension has been also documented to have association with increased risk of cerebro- and cardiovascular diseases ${ }^{3-6}$ chronic kidney disease, ${ }^{7}$ and insulin resistance, ${ }^{8}$ but not type 2 diabetes. ${ }^{9}$ It was significantly related to cerebrovascular disease with hazard ratio of $1.41^{3}$ and cardiovascular disease with relative risk of 
two. ${ }^{4}$ Prehypertension in young age $(<35$ years old $)$ was also associated with atherosclerosis of coronary artery 20 years later. ${ }^{10}$ But, prehypertension alone does not increase mortality, it significantly increases mortality in the presence of any other risk factor for cardiovascular disease. ${ }^{5}$

Based on WHO in 2012, prevalence of hypertension was decreasing globally from $32 \%$ in 1980 to $27 \%$ in 2008 . On the other hand, it was increasing in developing countries such as those in Africa and South East Asia region. ${ }^{11}$ Hypertension was reported in $24.8 \%$ of Indonesian men and $26.9 \%$ of Indonesian women. ${ }^{12}$ In 1999, National Health and Nutrition Examination Survey (NHANES) showed prevalence of prehypertension was $31 \%$ in USA. A survey held in Taiwan reported that $34 \%$ of adults had prehypertension. ${ }^{13}$ Based on Basic Health Research 2007, prevalence of prehypertension in Indonesian young adults (18-29 years old) was $48.4 \% .^{14}$

Prehypertension and hypertension complications have major impact on quality of life. ${ }^{2-4}$ Health promotion, early recognition, and prompt intervention play important roles in preventing their complications. ${ }^{1}$ This study was performed to know the prevalence of prehypertension and hypertension in young adults at a primary health care in a rural area in Indonesia.

\section{METHODS}

This study was conducted in a public health center (Puskesmas) located in a rural area, Cicurug, Sukabumi District, West Java Province, in September 2012. With ethical approval from the head of Cicurug Public Health Center, this study was started on $1^{\text {st }}-30^{\text {th }}$ of September 2012 on every Monday till Saturday. The procedures applied in this study were compliant with the Declaration of Helsinki.

In this cross-sectional study, the sample size was calculated for $95 \%$ confidence and $10 \%$ difference. In the calculations, we assumed that $50 \%$ of the population was normal, which resulted in a required samples size of 97 . With an expected $10 \%$ incomplete data, the minimal sample size was 107 young adults from our outpatient clinic in Cicurug Public Health Center. Young adults were defined as individuals who were 18 to 25 years old,${ }^{15}$ The exclusion criteria were pregnancy, refusal to get involved in this study, or having a hypovolemic, cardiogenic, or septic shock. We took the sample consecutively.

Twelve variables assessed were age, gender, weight, height, body mass index (BMI), systolic blood pressure, diastolic blood pressure, physical activity, sitting hours, smoking habit, alcohol drinking habit, and family history. All physical measurements (height, weight, systolic and diastolic blood pressure) were measured by trained health professionals. Yamamoto Giken ZT120 was used to measure weight and height. BMI was calculated by dividing weight $(\mathrm{kg})$ with square height $\left(\right.$ meter $\left.^{2}\right)$. We used Asia-Pacific BMI classification that is $>23$ as overweight and $>25$ as obesity. ${ }^{16}$ For the analysis, we merged the overweight and obese groups and compared them with normal and underweight groups.

Blood pressure was measured using a mercury sphygmomanometer as recommended in JNC 7. The classification of blood pressure was according JNC 7 which classifies as follows: normal $<120 \mathrm{mmHg}$ of systolic and $<80 \mathrm{mmHg}$ of diastolic pressure; prehypertension $120-139 \mathrm{mmHg}$ of systolic or 80 $89 \mathrm{mmHg}$ of diastolic pressure; hypertension $\geq 140$ $\mathrm{mmHg}$ of systolic or $\geq 90 \mathrm{mmHg}$ of diastolic pressure. ${ }^{1}$ A mercury sphygmomanometer Riester ${ }^{\circledR}$ was used.

Physical activity was assessed by conducting a direct interview to subjects using the International Physical Activity Questionnaires (IPAQ) which has been designed for population surveillance of physical activity among adults, adapted from the telephone version and translated to Indonesian language. The questionnaire was obtained from https://sites.google. com/site/theipaq/. Physical activity was classified into low, moderate, and high. ${ }^{17}$ For the analysis, we merged moderate and high activities.

Smoking habit was calculated with Brinkman Index, by multiplying cigarettes per day by years. The classification is non-, light, and heavy smoker. ${ }^{18}$ Alcohol drinking habit was also assessed, asking the amount and frequency.

One degree of family history of hypertension was also asked. If family history existed, we further differentiated it into mother's and father's side.

The statistical analysis was performed with $\operatorname{SPSS}^{\circledR}$, version 17.0. Prehypertensive and hypertensive groups were compared with normotensive group related to all measured variables. Kolmogorov-Smirnov test was used to assess the normality of the data. Numeric variables (age, weight, height, BMI) and their association with prehypertension and hypertension were analyzed using Mann-Whitney test. Categorical variables (family history-mother and father side; total activity-low, moderate-and-high; BMI-overweight and obese, underweight and normal) were analyzed using 
chi-square and Fisher exact test as the alternative. In addition, we also analyzed gender, family history (father or mother), categorized BMI, categorized total activity, and smoking history in systolic prehypertensive versus normotensive group and diastolic prehypertensive versus normotensive group.

\section{RESULTS}

From 111 young adults, males were $18 \%$ and females were $82 \%$. In our study, $34.2 \%$ had prehypertension and $17.1 \%$ had hypertension. Both of prehypertension and hypertension among male group were $25 \%$. In female group, prehypertension was $36 \%$ and hypertension was $15 \%$. Systolic hypertension and prehypertension were found $1.8 \%$ and $17.1 \%$, respectively. Diastolic hypertension and prehypertension were found $16.2 \%$ and $31.5 \%$. The description of demographic, metabolic, and behavioral characteristics among blood pressure (BP) groups was described in table 1. Only seven subjects had ever drunk alcohol and none of them drank it regularly.

Prehypertensive and hypertensive groups were compared with normotensive group. In numeric data, we found only weight in the hypertensive group that was significant $(p=0.01)$. In addition, weight in prehypertensive group $(\mathrm{p}=0.06)$ and BMI in hypertensive group $(\mathrm{p}=0.07)$ were seemed associated compared with normotensive group.

All subjects that smoked were light smokers. Compared with normotensive group, smoking was more often encountered in hypertensive and prehypertensive group. But, there were no association between smoking and BP groups in young adults (normotension vs hypertension, $\mathrm{p}=0.90$; normortension vs prehypertension, $\mathrm{p}=0.50$, Fisher test).
Family history from mother was seen higher in hypertensive (31.6\%) and prehypertensive (28.9\%) groups, but both of them were not associated compared with normotensive group (hypertensive $[\mathrm{p}=0.166]$; prehypertensive $[\mathrm{p}=0.16])$. From father side, the frequency was seen lower in hypertensive (10.5\%) and prehypertensive (13.2\%) groups without any association with hypertension $(\mathrm{p}=0.717$; Fisher test) and prehypertension $(\mathrm{p}=0.645)$.

When the total activity was categorized, low activity was found $83.3 \%$ in normotensive, $65.8 \%$ in prehypertensive, and $73.7 \%$ in hypertensive group. Moreover, it seemed that there was an association although it is not significant between activity and prehypertension $(\mathrm{OR}=2.6$; CI 95\% $=0.975-6.931 ; \mathrm{p}$ $=0.052)$, but no association with hypertension $(\mathrm{OR}=$ 1.758; CI 95\% $=0.513-6.241 ; p=0.498$, Fisher test).

We also categorized the BMI. Overall, 26.1\% of the subjects were underweight, $50.5 \%$ normal, $11.7 \%$ overweight, $9 \%$ obese 1 , and $2.7 \%$ obese 2 . Overweight and obesity were found in 36.8\% of hypertensive, in $28.9 \%$ of prehypertensive, and in $14.8 \%$ of normotensive groups. In other words, the percentage of overweight and obesity was found higher in prehypertensive than in normotensive groups. BMI was associated with hypertension ( $\mathrm{OR}=3.354$; CI 95\% $=1.013-11.102 ; \mathrm{p}=0.041)$, but not associated with prehypertension $(\mathrm{OR}=2.343$; CI 95\% $=0.839-6.544$; $\mathrm{p}=0.099)$.

Separately, we analyzed gender, family history (father or mother), categorized BMI, categorized activity, and smoking history in systolic prehypertensive vs normotensive groups and diastolic prehypertensive vs normotensive groups. We only found family history

Table 1. Demographic, metabolic, and behavioral characteristics of subjects by BP group (mean $\pm \mathrm{SD}$ )

\begin{tabular}{llll}
\hline Variables & $\begin{array}{l}\text { Normotensive } \\
(\mathrm{n}=54)\end{array}$ & $\begin{array}{l}\text { Prehypertensive } \\
(\mathrm{n}=38)\end{array}$ & $\begin{array}{l}\text { Hypertensive } \\
(\mathrm{n}=19)\end{array}$ \\
\hline Ages (years) & $20.9 \pm 2.3$ & $21.3 \pm 2.2$ & $21.2 \pm 2.5$ \\
Weight $(\mathrm{kg})$ & $46.2 \pm 6.3$ & $50.1 \pm 9.5$ & $54.3 \pm 12.4$ \\
Height $(\mathrm{cm})$ & $153 \pm 7.5$ & $153.4 \pm 7.5$ & $156.4 \pm 10.5$ \\
BMI $\left(\mathrm{kg} / \mathrm{m}^{2}\right)$ & $19.8 \pm 2.8$ & $21.2 \pm 4.2$ & $22.2 \pm 4.2$ \\
Systolic BP (mmHg) & $98 \pm 9.6$ & $109.5 \pm 9$ & $122 \pm 12.9$ \\
Diastolic BP (mmHg) & $66.4 \pm 5.2$ & $79 \pm 3.1$ & $90 \pm 3.3$ \\
Total activity (METS) & $552 \pm 996$ & $790 \pm 1104$ & $465 \pm 757$ \\
Sitting (minutes/week) & $1380 \pm 1119$ & $1441 \pm 1304$ & $1039 \pm 768$ \\
Smoking (\%) & 14.8 & 15.8 & 21.1 \\
Family History (\%) & 31.5 & 36.8 & 42.1 \\
Gender/male (\%) & 18.5 & 13.2 & 26.3 \\
\hline
\end{tabular}

*Fisher exact test 
$(\mathrm{OR}=3.045 ; \mathrm{CI} 95 \%=1.104-8.394 ; \mathrm{p}=0.027)$ and from mother side $(\mathrm{OR}=2.909 ; \mathrm{CI} 95 \%=1.021$ - 8.288; $\mathrm{p}=0.04)$ were associated with systolic prehypertension. Total activity was seemed associated with diastolic prehypertension $(\mathrm{OR}=2.504$; CI 95\% $=$ $0.944-6.642 ; \mathrm{p}=0.061)$.

\section{DISCUSSION}

Prehypertension is considered as a precursor of clinical hypertension. ${ }^{19}$ In our study, the prevalence of prehypertension and hypertension among young adults in a primary health care in rural area was $34.2 \%$ and $17.1 \%$, respectively. This finding is similar with review from Zhang and Li stating prevalence of prehypertension within adult population (31.6 - 39\%), not differentiating young adults. ${ }^{19}$ A further meta-analysis on the basis of 20 studies also found prevalence of prehypertension of $36 \%$ in an age group of $15-99$ years. ${ }^{20}$ In primary health care in Canada, prevalence of prehypertension was $30.6 \%$ in all adults, meanwhile hypertension diagnosed in $28 \%$ of adults. ${ }^{21}$ Among US adults (18 - 39 years), hypertension was found in $7.8 \%$. $^{22}$

Zarchi and Gahangiri ${ }^{23}$ found systolic prehypertension $(61.6 \%)$ and hypertension $(4.6 \%)$ and also diastolic prehypertension (61\%) higher in Tehran. Only diastolic prehypertension was found lower than our study $(9.9 \%)$.

We separately assessed some studies that included young adults or differentiated age groups to the prevalence. Wang and Wang ${ }^{22}$ showed the prevalence of prehypertension was $32 \%$ and hypertension was $27 \%$ among an age group of $18-39$ years in the USA. Kitai et $\mathrm{al}^{24}$ showed prehypertension prevalence of $40 \%$ in an age group of $18-25$ years in Israel excluding no data subjects. Ejike et $\mathrm{al}^{25}$ showed prehypertension prevalence of about $32 \%$ among 18 years-old subjects in semi-urban or urban areas in Nigeria. In their study, Choi et $\mathrm{al}^{26}$ found that per 10 years, age increased 1.2 times of risk to develop prehypertension and 2.3 times of risk to develop hypertension. Their estimated age-adjusted prevalence of hypertension was $22.9 \%$. Among continents, the prevalence was not so different. So, we suggest that geographical distribution influence is minor; thus, results can be applied globally and also in rural and urban areas.

\section{Gender}

We found prehypertension is more prevalent in female subjects compared with male subjects. This is inconsistent with most literature, ${ }^{2,19,27-29}$ but going along with studies in Turkey. ${ }^{30-33}$ There are some hypotheses why our study showed greater prevalence in female rather than male subjects. First, it may be caused by imbalanced proportion between male and female patients who visited to the outpatient ward. Second, females were more aware of their health than males. ${ }^{30}$ Although prehypertension or hypertension was not presented with any symptoms,${ }^{34}$ our subjects were patients who had other complaints related to main disease. So, we suggest that males were less likely to seek treatment or just undergo general check-up.

Another reason for our finding may be the differential distribution of risk factors (e.g. genetic predisposition, dietary factors, lack of physical activity) between women and men across populations as stated by Yu et al. ${ }^{27}$ It is important to mention that in studies conducted in Israel $^{13}$ and rural China ${ }^{35}$ prevalence of prehypertension remained constant across age groups among men but increased with age among women. ${ }^{13,35}$ Associated risk factors such as body mass index, waist circumferences, fasting plasma glucose, total cholesterol, and LCL-C were all also more significant in women, which may be related to sex hormones. ${ }^{20}$

These findings concluded that prehypertension and hypertension linked with gender differences apparently present although vary between cultures. It implicates the influences of interaction between social and biological mechanism. ${ }^{20}$ Therefore, it is important to increase the awareness in young adults regardless of their gender to do routine check-up since it leads to early detection of prehypertension and hypertension.

\section{Physical activity}

Low activity has been stated to associate with incidence of hypertension. According to the study by Erem et $\mathrm{al}^{25}$ the prevalence of hypertension increases when physical activity decreases $(\mathrm{p}<0.001)$. On the other hand, a study on female students in Dammam, Saudi Arabia revealed that physical inactivity was not associated with prehypertension. ${ }^{29}$ From our study, it seemed that there was an association between physical activity and prehypertension $(\mathrm{OR}=2.6$; CI 95\% $=0.975-6.931$; $\mathrm{p}=0.052)$, but no association with hypertension $(\mathrm{p}=$ 0.498 , Fisher test).

Both aerobic and resistance training have been found to have positive effects on lowering systolic and diastolic blood pressure $(-3.84 \mathrm{mmHg}$ and $-2.58 \mathrm{mmHg}$, respectively), as stated in two meta-analyses. ${ }^{19,20}$ If we examine the blood pressure reduction of the metaanalyses, it might be statistically but not clinically significant. 
A study was conducted in Japan to search for the appropriate type and frequency of physical activity that should be performed. ${ }^{14}$ It was found that increasing daily total activity contributed to lowering hazard ratio in developing prehypertension. ${ }^{19} \mathrm{We}$ suggest that the inconsistent results might be caused by lack of uniformity in assessing total physical activity.

Therefore, encouraging active lifestyle is still important to have a better control of one's blood pressure since young adults, as well as increasing physical activity in form of aerobic and/or resistance training. A study found that rural areas were usually lack of efforts for health promotion and education, thus creating lower awareness of detecting and treating high blood pressure. ${ }^{27}$ Population in rural area are in need of "active lifestyle campaign" since they located far from the urban or city and less government program is being well established at this rural area.

\section{BMI}

Many studies have stated that BMI was strongly related with prehypertension and hypertension. 19,27,29,30,36,37 Pang et $\mathrm{al}^{35}$ specifically found associations between BMI and elevated blood pressure. We found that overweight and obese subjects were more likely to develop prehypertension and hypertension, since overweight and obesity were more prevalent in prehypertensive and hypertensive than in normotensive groups.

A meta-analysis concluded that higher body mass index and waist circumferences indicating excess weight conditions were related to prehypertension and hypertension. Weight reduction is reasonably concluded to give the same effect of lowering BP both to hypertension and prehypertension. ${ }^{20}$ Grotto et al ${ }^{13}$ suggested that obesity was a major determinant of prehypertension even after controlling the other risks, such as age and sedentary lifestyle.

Our result showed only hypertension statistically associated with BMI $(\mathrm{OR}=3.354$; CI 95\% $=1.013$ $11.102 ; \mathrm{p}=0.041$ ), possibly due to subject numbers too small to conclude that prehypertension association with BMI does exist. Yet the percentage of overweight subjects was still higher in prehypertension group (28.9 $\%)$ than normotensive group (14.8\%). Yu et $\mathrm{al}^{27}$ found that decreasing one SD of BMI $\left(3.23 \mathrm{~kg} / \mathrm{m}^{2}\right.$ for men and $3.50 \mathrm{~kg} / \mathrm{m}^{2}$ for women) was related with decreasing the risk of prehypertension 1.36-fold for men and 1.49-fold for women. ${ }^{22}$ Prehypertensive subjects in resource-poor settings such as rural areas might be benefited from early promotion of healthy body weight, so it would not develop to hypertension condition which needs long-term control program.

\section{Family history}

Family history plays a role in prehypertension and hypertension as one of the findings in this study. This goes along with literature, which states that family history of obesity, diabetes, hypertension and atherosclerotic heart disease is higher in patients with hypertension than in healthy subjects. ${ }^{38,39}$ However, none of these studies differentiated between family history from mother's and father's side.

On the other hand, a study by Yadav et $\mathrm{al}^{40}$ on urban population in North India showed that family history of hypertension was an important contributor to hypertension but not to prehypertension, while the reason was not clear. Chobanian et $\mathrm{al}^{1}$ also stated in JNC 7 that genetic of hypertension remained unclear. ${ }^{1}$

Nevertheless awareness of subjects whose positive family history to check their health routinely, and develop proper lifestyle is essential for reducing the morbidity of prehypertension and hypertension among population.

\section{Alcohol drinking and smoking habit}

There are no subjects with regular alcohol drinking habits in our study. Alcohol consumption exceeding the amount recommended by JNC-7 may elevate blood pressure. As global estimates indicate, alcohol contributes to $16 \%$ of hypertension cases. However, this condition is reversible within 2-4 weeks of abstinence. ${ }^{19}$ Only seven subjects in our study had ever drunk alcohol, which means that alcohol consumption does not play a role and makes further analysis in the context of this study impossible.

Although we did not see an association between smoking and prehypertension in young adults, smoking habits were more prevalent in hypertensive and prehypertensive groups. Although Glasser et $\mathrm{al}^{41}$ and Koura et $\mathrm{a}^{29}$ found similar results, our result was inconsistent with several other studies that showed association between smoking and prehypertension or hypertension. ${ }^{42,43} \mathrm{~A}$ reason for this discrepancy may be that smoking raises BP acutely, but can increase cerebro- and cardiovascular disease through chronic atherogenic processes. ${ }^{1,44}$

In case of prehypertension, medication is not indicated since lifestyle modification is sufficient to reduce blood pressure, except in some conditions such as diabetes mellitus, kidney disease, and failure in reducing 
blood pressure after adequate lifestyle modification. These changes include weight loss, high-fiber lowfat diet, restriction of daily sodium intake, regular aerobic physical activity, and cessation of smoking and consuming alcohol.

In conclusion, prevalence of prehypertension and hypertension were high among young adults in a primary health care in Cicurug, a rural area, so we must encourage routine examination and early intervention to decrease morbidity and mortality through development of cerebrovascular, cardiovascular, and chronic kidney diseases. This condition should not be underestimated and prompt life-style changes of proper diet and adequate physical activity are mandatory to young adults, before other risk factors occur. Most of the prehypertension risk factors are modifiable especially by lifestyle changes. By preventing prehypertension conditions to develop further to hypertension, it will help to reduce the burden of health care systems in term of pharmacotherapy and complication treatment costs.

The limitation of our study is that our subjects were not suitable to analyze all risk factors. Moreover, we did our study in a public health care center, which may not represent all population in the area, because most people who go to these public health care centers have a low economic status. Furthermore, a limited number of studies on prehypertension and hypertension in young adults is available to be compared with our study.

\section{REFERENCES}

1. Chobanian AV, Bakris GL, Black HR, et al. The Seventh Report of the Joint National Committee on prevention, detection, evaluation, and treatment of high blood pressure: the JNC 7 report. JAMA. 2003;289:2560-72.

2. Ferguson TS, Younger N, Tulloch-Reid MK, et al. Progression from prehypertension to hypertension in a Jamaican cohort: incident hypertension and its predictors. West Indian Med J. 2010;59:486-93.

3. ArimaH,MurakamiY,LamTH, etal.Effects of prehypertension and hypertension subtype on cardiovascular disease in the Asia-Pacific Region. Hypertension. 2012;59:1118-23.

4. Liszka HA, Mainous AG, 3rd, King DE, et al. Prehypertension and cardiovascular morbidity. Ann Fam Med. 2005;3:294-9.

5. Mainous AG, 3rd, Everett CJ, Liszka H, et al. Prehypertension and mortality in a nationally representative cohort. Am J Cardiol. 2004;94:1496-500.

6. Lee M, Saver JL, Chang B, et al. Presence of baseline prehypertension and risk of incident stroke: a metaanalysis. Neurology. 2011;77:1330-7.

7. Kanno A, Kikuya M, Ohkubo T, et al. Pre-hypertension as a significant predictor of chronic kidney disease in a general population: the Ohasama Study. Nephrol Dial Transplant. 2012;27:3218-23.
8. Player MS, Mainous AG, 3rd, DiazVA, etal. Prehypertension and insulin resistance in a nationally representative adult population. J Clin Hypertens (Greenwich). 2007;9:424-9.

9. Mullican DR, Lorenzo C, Haffner SM. Is prehypertension a risk factor for the development of type 2 diabetes? Diabetes Care. 2009;32:1870-2.

10. Pletcher MJ, Bibbins-Domingo $\mathrm{K}$, Lewis $\mathrm{CE}$, et al. Prehypertension during young adulthood and coronary calcium later in life. Ann Intern Med. 2008;149:91-9.

11. World Health Organization. World health statistics 2012. Geneva: World Health Organization; 2012.

12. Nguyen TT, Adair LS, Suchindran CM, et al. The association between body mass index and hypertension is different between East and Southeast Asians. Am J Clin Nutr. 2009;89:1905-12.

13. Grotto I, Grossman E, Huerta M, et al. Prevalence of prehypertension and associated cardiovascular risk profiles among young Israeli adults. Hypertension. 2006;48:254-9.

14. Rachmawati R, Permanasari Y. Higher body mass index may increase prehypertension risk. Health Science Indones. 2011;2:21-7.

15. U.S. Department of Health and Human Services: Substance Abuse and Mental Health Services Administration. National household survey on drug abuse: main findings 1996: Office of Applied Studies, Substance Abuse and Mental Health Service Administration, Department of Health \& Human Services; 1998.

16. World Health Organization, International Obesity Task Force and International Association for the Study of Obesity. The Asia-Pacific perspective: redefining obesity and its treatment. Sydney: Health Communications Australia Pty Ltd; 2000.

17. IPAQ Research Committe. Guidelines for data processing and analysis of the international physical activity questionnaire (IPAQ) [Internet]. 2005 [cited 1 Sept 2012]. Available from: www.ipaq.ki.se/scoring.pdf.

18. Watanabe N, Fukushima M, Taniguchi A, et al. Smoking, white blood cell counts, and TNF system activity in Japanese male subjects with normal glucose tolerance. Tob Induc Dis. 2011;9:12.

19. Zhang W, Li N. Prevalence, risk factors, and management of prehypertension. Int J Hypertens. 2011;2011:605359.

20. Guo X, Zou L, Zhang X, et al. Prehypertension: a metaanalysis of the epidemiology, risk factors, and predictors of progression. Tex Heart Inst J. 2011;38:643-52.

21. Godwin M, Pike A, Kirby A, et al. Prehypertension and hypertension in a primary care practice. Can Fam Physician. 2008;54:1418-23.

22. Wang Y, Wang QJ. The prevalence of prehypertension and hypertension among US adults according to the new joint national committee guidelines: new challenges of the old problem. Arch Intern Med. 2004;164:2126-34.

23. Zarchi AAK, Gahangiri M. Prehypertension and hypertension in Iranian military personnel: prevalence according to some related factors. World Appl Sci J. 2010;11:541-7.

24. Kitai E, Vinker S, Halperin L, et al. Pre-hypertension is a common phenomenon: national database study. Isr Med Assoc J. 2007;9:8-11.

25. Ejike CE, Ugwu CE, Ezeanyika LU. Variations in the prevalence of point (pre)hypertension in a Nigerian schoolgoing adolescent population living in a semi-urban and an urban area. BMC Pediatr. 2010;10:13. 
26. Choi KM, Park HS, Han JH, et al. Prevalence of prehypertension and hypertension in a Korean population: Korean National Health and Nutrition Survey 2001. J Hypertens. 2006;24:1515-21.

27. Yu D, Huang J, Hu D, et al. Prevalence and risk factors of prehypertension among Chinese adults. J Cardiovasc Pharmacol. 2008;52:363-8.

28. Arafa NAS, Ez-Elarab HS. Epidemiology of prehypertension and hypertension among Egyptian adults. The Egyptian Journal of Community Medicine. 2011;29:1-18.

29. Koura MR, Al-Dabal BK, Rasheed P, et al. Prehypertension among young adult females in Dammam, Saudi Arabia. East Mediterr Health J. 2012;18:728-34.

30. Erem C, Hacihasanoglu A, Kocak M, et al. Prevalence of prehypertension and hypertension and associated risk factors among Turkish adults: Trabzon Hypertension Study. J Public Health (Oxf). 2009;31:47-58.

31. Altun B, Arici M, Nergizoglu G, et al. Prevalence, awareness, treatment and control of hypertension in Turkey (the PatenT study) in 2003. J Hypertens. 2005;23:1817-23.

32. Sonmez HM, Basak O, Camci C, et al. The epidemiology of elevated blood pressure as an estimate for hypertension in Aydin, Turkey. J Hum Hypertens. 1999;13:399-404.

33. Tugay Aytekin N, Pala K, Irgil E, et al. Distribution of blood pressures in Gemlik District, north-west Turkey. Health Soc Care Community. 2002;10:394-401.

34. Bensenor IM. Hypertension and headache: a coincidence without any real association. Sao Paulo Med J. 2003;121:183-4.

35. Pang W, Sun Z, Zheng L, et al. Body mass index and the prevalence of prehypertension and hypertension in a Chinese rural population. Intern Med. 2008;47:893-7.
36. Ishikawa $\mathrm{Y}$, Ishikawa J, Ishikawa S, et al. Prevalence and determinants of prehypertension in a Japanese general population: the Jichi Medical School Cohort Study. Hypertens Res. 2008;31:1323-30.

37. Kawamoto R, Kohara K, Tabara Y, et al. High prevalence of prehypertension is associated with the increased body mass index in community-dwelling Japanese. Tohoku J Exp Med. 2008;216:353-61.

38. Shanthirani CS, Pradeepa R, Deepa R, et al. Prevalence and risk factors of hypertension in a selected South Indian population--the Chennai Urban Population Study. J Assoc Physicians India. 2003;51:20-7.

39. Jenei Z, Pall D, Katona E, et al. The epidemiology of hypertension and its associated risk factors in the city of Debrecen, Hungary. Public Health. 2002;116:138-44.

40. Yadav S, Boddula R, Genitta G, et al. Prevalence \& risk factors of pre-hypertension \& hypertension in an affluent north Indian population. Indian J Med Res. 2008;128:712-20.

41. Glasser SP, Judd S, Basile J, et al. Prehypertension, racial prevalence and its association with risk factors: Analysis of the REasons for Geographic And Racial Differences in Stroke (REGARDS) study. Am J Hypertens. 2011;24:194-9.

42. Ferguson TS, Younger NO, Tulloch-Reid MK, et al. Prevalence of prehypertension and its relationship to risk factors for cardiovascular disease in Jamaica: analysis from a cross-sectional survey. BMC Cardiovasc Disord. 2008;8:20.

43. Yang J, Lu F, Zhang C, et al. Prevalence of prehypertension and hypertension in a Chinese rural area from 1991 to 2007. Hypertens Res. 2010;33:331-7.

44. Nakamura K, Barzi F, Lam TH, et al. Cigarette smoking, systolic blood pressure, and cardiovascular diseases in the Asia-Pacific region. Stroke. 2008;39:1694-702. 